ate of Alaska

Department of Natural Resources

DIVISION OF MINES AND MTIERALS
P. 0. Box 1391

Junean, Alaska

Vol. VII

No. 7

\title{
MINIING ACTIVITISS
}

FIRSI DIVISION - A ayndicate managed by Moneta Porcuplne Itd. of Toronto staked a new copper property last year and is now drilling it. The prospect is located above Eadicott Arm, between Juneau and Peteraburg.

Prospecting act1vities have accelereted recently in the First Division, and there s now considerably more exploration in progress along the Panhandle than was earlier antic1pated.

According to the Southeast Stevedore Company of Ketchikan, it has been hired to load 5,000 tons of iron ore from Haines. This ore would come from the Klukwan deposit, presently being explored by Columbia Iron Mining Company, a subsidiary of U.S. Steel.

SECOND DIVISION - Bear Creek Mining Company (Kennecott) 16 drilling for the third ouccessive season on the Kuby Creek copper show on Kuby Creek north of the Kobuk R1ver near Shungmak. There 18 a crew of about 38 men on the property this year.

THIRD DIVISION - A new Manitowoc Model 4500 dragline was christened with a bottle of champegne at the Minor Roop call strip pit recently. It hes a 120 -foot bocm.

\section{OII NEWS}

The State Diviaton of Lands bas scheduled a public hearing on proposed mules and regulations for ofl and gas leaging on State lands. Copies of the proposed regulatlons and proposed forms to be used have been widely distributed, and more are available at the Division of Lands, $333 \mathrm{D}$ Street, Anchorege. Passible future applicants for State oll and gas lands are lavited to attend and present thelr views. The proposed rules cover such matters as avallability of land for leasing, qualiflcations, limitatlons, rentals, royalties, practices and procedures goveming competitive and noncompetitive regulations, forms to be used for the varlous functions, etc. Those attending the meeting should be prepared to discuss any points or subjects within the scope of bidding and leasing on which they heve definite oplnions. Problems in the realn of policy rather then regulations auch as the need for varlous faclilities in connectlon with offshore and onsiore production will also be discussed. Regulations will become effective 30 days after action on changes made at the hearing. The hesring will be at the Z. J. Loussac Iibrary in Anchorage on July 9.

Standard and Richfield are still working on thels directlonal redrill of Swenson River Unit No. 4 well. Union and Ohio are down to 8,000 feet in the Kenal Unit Well No. 1. Anchorage Gas and 011 Development Company is drilling at 4,200 near Houbton. laska Consolidated 011 is below 7,000 feet at Iniskin. General Petroleum and Great Basins are now rigging up for Becharof No. 1 well in the Nushogak Basin. 


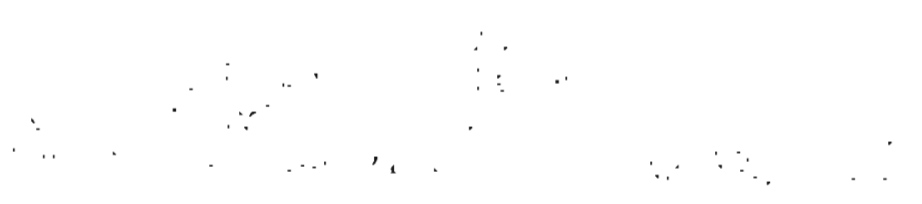

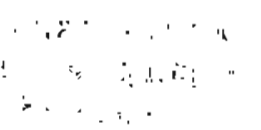

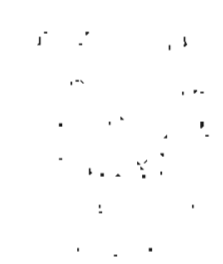

$\therefore \quad \cdots$

$\therefore$ 
"Gold in melted or treated form may be sold or disposed of only by a person or concern operating under a:Treasury gold license authorizing the disposition of gole in such form.

"The Secretary of the Treasury, subject to the approvel of the Fresident, has authority to revoke or modify the Gold Regulations."

\section{DEPARTMENT OF IRTERIOR COAL-LEASIIVG STATTMMNNT}

The quotation below. Is: a portion of a letter from the Department of the Interior to Representative Aspinall, Chaiman of the House Interior Committee. Representative Aspinall had requested the Department to state its views on H.R. 6939, $\varepsilon$ bill to increase the acreage limitation on leasing coal lands in Alaska to 30,720 acres from the present 2,560 .

"The present acreage Itritation imposed by the Alaska Coal Lands Act is intended to prevent monopoly. However, we can discover little danger. of that in the coal industry, and we believe that any danger of monopoiy. which opes exist can best be overcome by encouraging the development of further resources. The present restriction applicable to Alaska is so stringent that it tends to discourage investment in coal mining there, and if the Federal Government 18 to permit the more complete utilization of low and medium grade coel deposits under more modern methads of mechanized mining an increase in the acreage limitation appears necessary. Under the geologic conditions prevailing in Alaska coal deposits in many cases are variable and unpredictable. Lessees operating more than one mine and mining more than one type of coel may find it imperative that they be permitted to acquire additional land without giving up the land now being worked by them. In many cases isolated areas at the present time cannot be developed because before they can be leased, existing operations must be dropped. An increase in the acreage linitation would probably encourage many exlsting lessees to explore and develop larger areas than they may at the present time hold under lease. At the present time there is increased interest in coal production in Alaska for foreign export. We believe that every effort should be made to induce the timely and proper development in Alaska's coal resources. Accordingly, we feel that an increase in the maximum acreage which may be held under coal lease in Alaska is deslrable; however, we do not at this time favor the increase proposed by H.R. 6939."

The letter then goes on to state that the Department of the Interfor does favor an Increase to 20,480 acres for Alaska, and w1ll not object to passage of the bill if the proposed ecreage limitation is reduced to that amount.

ETCETERA

An apparently well informed helicopter pilot informs us that there are at least 90 "choppers" working in Alaska this sumer. Most are in oil exploration, of course, but their use by mining firms is increasing steadily.

From the mmber of requests that came in, it lookg as if we will have to make good on our offer to mimeograph the paper "The Construction and Operation of Mining Camps n Northern Lat1tudes," although we bave beenpromised reprints of the article from the magazine Western Miner and O1I Review iP it can secure the paper for publicat1on. Either way, we will see to It that all who have requested it, and others who may yet request $1 t$, will recelve copies. 
E. AND M. J. METAL MARKET PRICES

\begin{tabular}{|c|c|c|c|}
\hline & $\begin{array}{l}\text { June } 25 \\
1959 \\
\end{array}$ & $\begin{array}{l}\text { Month } \\
\text { Ago }\end{array}$ & $\begin{array}{l}\text { Year } \\
\text { Ago }\end{array}$ \\
\hline 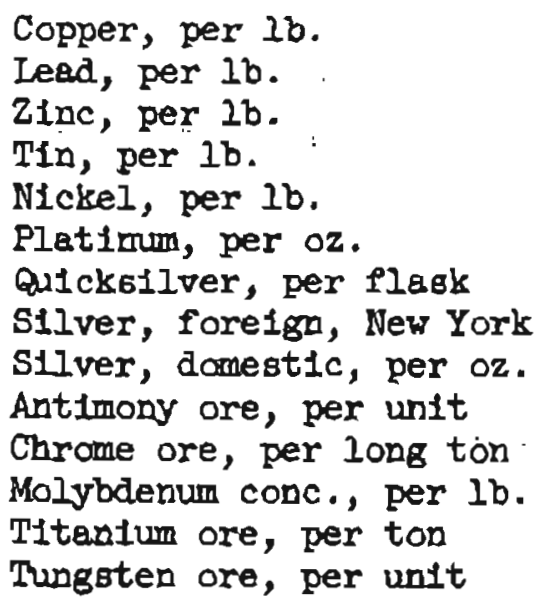 & $\begin{array}{l}31.5 \phi \\
12 \phi \\
11 \phi \\
103.4 \phi \\
74 \phi \\
\$ 76-80 \\
\$ 239-241 \\
91.4 \phi \\
90.5 \phi \\
\$ 3.10-3.20 \\
\$ 35-36 \\
\$ 1.25 \\
\$ 23-26 \\
\$ 20-22\end{array}$ & $\begin{array}{l}31.64 \\
12 \phi \\
11 \phi \\
102.3 \phi \\
74 \phi \\
\$ 76-80 \\
\$ 245-247 \\
91.4 \phi \\
90.5 \phi \\
\$ 3.10-3.20 \\
\$ 40-42 \\
\$ 1.25 \\
\$ 23-26 \\
\$ 20-22\end{array}$ & $\begin{array}{l}25.24 \\
11.54 \\
104 \\
94.84 \\
74 \phi \\
\$ 62-70 \\
\$ 228-230 \\
89.6 \phi \\
90.54 \\
\$ 3.00-3.10 \\
\$ 46-48 \\
\$ 1.18 \\
\$ 23-26 \\
\$ 17-22\end{array}$ \\
\hline
\end{tabular}

